\title{
The Effects of Supplemented Diets with Turmeric Powder on Pigmentation and Growth of Yellow Tail Cichlid Pseudotropheus acei (Regan 1922)
}

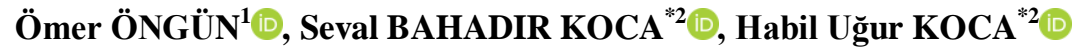 \\ ${ }^{1}$ Süleyman Demirel University, Graduate School of Natural and Applied Sciences, Aquaculture Department, Isparta, \\ Turkey \\ ${ }^{2}$ Isparta University of Applied Science, Eğirdir Fisheries Faculty, Isparta, Turkey
}

*Corresponding Author: sevalkoca1@hotmail.com

Received 31 January 2021; Accepted 09 May 2021; Release date 01 September 2021.

How to Cite: Öngün, Ö., Bahadır Koca, S., \& Koca, H. U. (2021). The effects of supplemented diets with turmeric powder on pigmentation and growth of yellow tail cichlid Pseudotropheus acei (Regan 1922). Acta Aquatica Turcica, 17(3), 386394. https://doi.org/10.22392/actaquatr.865465

\begin{abstract}
There are few studies about the effect of turmeric powder on the skin pigmentation of fish in the literature. This study was conducted to research body and tail pigmentation and growth performance of Pseudotropheus acei (Regan 1922) fed supplemented diets with different ratio turmeric (Curcuma longa) powder. Five diets were prepared by adding four different ratios of turmeric powder (T1: 1\%, T3: 3\%, T5: 5\%, and T7: 7\% ) to C: control diet (without turmeric powder). A total of 75 broodstock (mean weight $6 \mathrm{~g}$ ) were randomly stocked $\left(4 \circ: 1{ }^{\Uparrow}\right)$ in 15 aquariums $(70 \times 30 \times 40 \mathrm{~cm})$, with three replications. The fish were fed twice daily at 8:30 and 20:30 with the diets supplemented turmeric as ad libitum during the 90 days.

At the end of the experiment, the body and tail pigmentation of $P$. acei significantly increased with increasing turmeric rate in diets $(\mathrm{P}<0.05)$. The blue indicator $-\mathrm{b}$ values in male and female body color were high in all turmeric supplemented groups compared to the control group $(\mathrm{P}<0.05)$. Also, the yellow color indicator $+b$ value in the color of the male and female tail increased with the addition of turmeric. $\mathrm{H}_{\mathrm{ab}}$ values were determined in the blue area for the body and in the yellow area for the tail. However, pigmentation of all groups supplemented turmeric powder was visually not different from the color of the control group. There were no significant differences between final weights, weight gain SGR, FCR, and survival rates of $P$. acei fed diets supplemented with turmeric powder compared to the control $(\mathrm{P}>0.05)$. As a result of the study, skin and tail pigmentation and growth performance of $P$. acei were not improved by supplementing with turmeric powder to diets.
\end{abstract}

Keywords: Pseudotropheus acei, Curcuma longa, growth performance, pigmentation

Zerdeçal Tozu İlave Edilmiş Diyetlerin Sarı Kuyruk Çiklit Pseudotropheus acei (Regan 1922)'nin Vücut Pigmentasyonu ve Büyüme Performansı Üzerindeki Etkileri

\section{Özet}

Literatürde, zerdeçal tozunun balıkların vücut ve kuyruk pigmentasyonu üzerindeki etkilerinin belirlendiği az sayıda çalıșma bulunmaktadır. Bu çalışma, farklı oranlarda zerdeçal (Curcuma longa) tozu ilaveli diyetlerle beslemenin Pseudotropheus acei'nin (Regan 1922) vücut-kuyruk pigmentasyonu ve büyüme performansina etkilerini belirlemek amaciyla oluşturuldu. Dört farklı oranda zerdeçal tozu (T1:\% 1, T3:\% 3, T5:\% 5 ve T7:\% 7) C: kontrol diyetine (zerdeçal tozu olmadan) eklenerek beş diyet hazırlanmıştır. Toplam 75 anaç (ortalama ağırlık $6 \mathrm{~g}$ ) 15 akvaryumda $(70 \times 30 \times 40 \mathrm{~cm})$ üç tekerrürlü olarak rastgele stoklanmıştır $\left(4\right.$ 웅 $\left.1 \bigcirc^{\Uparrow}\right)$. Balıklar, 90 gün boyunca doyuncaya kadar zerdeçal ilaveli diyetler ile günde iki kez saat 8:30 ve 20:30 da beslenmişlerdir. Denemenin sonunda, diyetlerdeki zerdeçal oranının artmasıyla $P$. acei'nin vücut ve kuyruk pigmentasyonu önemli ölçüde arttığı belirlenmiştir $(\mathrm{P}<0,05)$. Erkek ve dişi vücut rengindeki mavi renk göstergesi $-\mathrm{b}$ değerleri tüm zerdeçal ilaveli gruplarda kontrol grubuna göre yüksek bulunmuştur $(\mathrm{P}<0,05)$. Ayrıca zerdeçal ilavesiyle erkek ve dişi kuyruk rengindeki sarı renk göstergesi $+b$ değeri artmıştır. $H_{a b}$ değerleri vücut için mavi, kuyruk için sarı alanda belirlenmiştir. Bununla birlikte, zerdeçal tozu ilaveli tüm grupların pigmentasyonu görsel olarak kontrol grubunun renginden farklı değildi. Kontrole kıyasla zerdeçal tozu ilaveli diyetler ile beslenen $P$. acei final ağırlık, ağırlık kazancı SGR, FCR ve yaşama oranları arasında önemli bir farklılık tespit edilmemiştir $(\mathrm{P}<0,05)$. Sonuç olarak, $P$. acei'nin diyetlerine zerdeçal tozu ilavesi vücut ve kuyruk pigmentasyonu ve büyüme performansı verilerini iyileştirmedi.

Anahtar Kelimeler: Pseudotropheus acei, Curcuma longa, büyüme performansı, pigmentasyon

\section{INTRODUCTION}

Ornamental fish demand increase worldwide every year (Srikrishnan et al., 2017). One of the most attractive features of ornamental fish is undisputed their colors (Kop and Durmaz, 2008). Pigmentation 
of fish demonstrates its quality and wellness. Especially, the colors of male fishes become brighter (Alpbaz and Hoşsucu, 1996). The lively colors in the fish, as well as fish species, is one of the considerable determinants of the marketing of fish (Hatlen et al., 1997). Ornamental color fish production is an important issue for producers (Hekimoglu, 2005). It is known that many types of diet are marketed for the coloration of fish in different countries recently (Brineshrimp Direct, 2005).

The fish cannot synthesize carotenoids like other animals, and they must obtain from diets (Sommer et al., 1991). Both synthetic and natural carotenes are used in the coloration of fish. But the synthetic carotenoids causes some health problems, there is an increasing demand for the elimination of the use of synthetic carotenes (Ambati et al., 2019; Mohammed and Mohd, 2011). Natural carotenoids are derived from plants while synthetic ones are mainly by-products from coal distillation (Ambati et al., 2019; Carbonell-Capella et al., 2014). Recently, natural carotenoids were started using due to the toxic effect of synthetic carotenoid pigments ( Ambati et al., 2019). Antioxidant activity is better in the case of natural carotenoids, unlike synthetic ones. (Murthy et al., 2005). In addition, synthetic carotenoids added to feeds increase the price of feed by $20-25 \%$ (Yesilayer et al., 2008). The cichlid fish is a take part in the species which people excessively prefer on the world. Pseudotropheus acei is found in shallow water on a clear sandy bottom and in bogs in Lake Malawi (Parry et al., 2005).

Turmeric is a spice that comes from the root of Curcuma longa, a member of the ginger family, Zingaberaceae (Chainani-Wu N., 2003). Curcumin, an active component of turmeric, is a yellow pigment that has been isolated from the ground rhizome part of the curcuma plant curcumin; has antiinflammatory, antioxidant, anticancerogenic, and hypolipidemic properties (Tayyem et al., 2006).

A study was done on pigmentation of fish; Mukherjee et al., (2009) reported that high pigmentation was observed in caudal fin and muscle of fish $(P$. reticulata) fed with diets added turmeric powder $(0.09 \%)$. For this aim, we researched the pigmentation effect of turmeric powder in different fish Pseudotropheus acei (Regan 1922) that has yellowfins. For this aim, we researched the pigmentation effect of turmeric powder in the diet at the different ratios on fish Pseudotropheus acei (Regan 1922) pigmentation that has yellowfins.

\section{MATERIAL and METHOD \\ Experimental diets}

Experimental diets were isonitrogenous ( $37 \%$ crude protein) and isoenergetic (4400kcal). Five diets were prepared by adding four different ratios of turmeric powder (T1: 1\%, T3: 3\%, T5: 5\%, and T7: 7\%) to C: control diet (without turmeric powder). The composition of the diets is shown in Table 1. The feed ingredients were supplied from a local fish feed manufacturer. Turmeric powder was obtained from a special spice seller (Isparta, Turkey). All ingredients were ground to small particle size $(0.5 \mathrm{~mm})$ in a mill. Dietary ingredients were mixed in a mixer. Micro ingredients were first mixed and then slowly added to the macro ingredients to ensure a homogenous mixture. Water was added to obtain a 30\% moisture level. Diets were passed through a mincer with a $1 \mathrm{~mm}$ sieve. The pellets were fan-dried and stored frozen at $-20^{\circ} \mathrm{C}$ until used. 
Table 1. Formulation and proximate composition of experimental diets

\begin{tabular}{llllll}
\hline \hline Ingredients (\%) & C & T 1 & T3 & T5 & T7 \\
\hline Turmeric & 0.00 & 1.00 & 3.00 & 5.00 & 7.00 \\
Fish meal & 35.00 & 35.00 & 35.00 & 35.00 & 35.00 \\
Soybean & 22 & 22 & 22 & 22 & 22 \\
Corn starch & 7.00 & 6.00 & 4.00 & 2.00 & 0.00 \\
Wheat & 26 & 26 & 26 & 26 & 26 \\
Fish oil & 7.00 & 7.00 & 7.00 & 7.00 & 7.00 \\
Vitamin mix & 1.00 & 1.00 & 1.00 & 1.00 & 1.00 \\
Mineral mix $^{2}$ & 1.00 & 1.00 & 1.00 & 1.00 & 1.00 \\
Pellet binder & 1.00 & 1.00 & 1.00 & 1.00 & 1.00 \\
\hline Chemical Analyses & & & & & \\
\hline Crude protein (\%) & 36.91 & 36.99 & 37.15 & 37.31 & 37.47 \\
Crude lipid (\%) & 10.24 & 10.30 & 10.41 & 10.53 & 10.65 \\
Crude fiber (\%) & 1.75 & 1.80 & 1.89 & 1.98 & 2.07 \\
Crude ash (\%) & 9.33 & 9.33 & 9.33 & 9.33 & 9.33 \\
Gross energy ( kcal ) & 4426.33 & 4423.71 & 4418.47 & 4413.23 & 4407.99 \\
\hline \hline
\end{tabular}

Vitamin premix. ${ }^{1}$; per kg, 4,000,000 IU vitamin A, 480,000 IU vitamin D3, 40,000 mg vitamin E, $2400 \mathrm{mg}$ vitamin $\mathrm{K} 3,4,000 \mathrm{mg}$ vitamin $\mathrm{B} 1,6,000 \mathrm{mg}$ vitamin $\mathrm{B} 2,40,000 \mathrm{mg}$ niacin, 10,000 $\mathrm{mg}$ calcium D-pantothenate, 4,000 mg vitamin B6, $10 \mathrm{mg}$ vitamin B12, $100 \mathrm{mg}$ D-biotin, 1,200 $\mathrm{mg}$ folic acid, 40,000 mg vitamin $\mathrm{C}$ and 60,000 mg inositol. Mineral premix. ${ }^{2}$; per $\mathrm{kg}$ 23,750 mg Mn, 75,000 mg Zn, 5,000 mg Zn, 2,000 mg Co, 2,750 mg I, $100 \mathrm{mg} \mathrm{Se,} \mathrm{200,000} \mathrm{mg} \mathrm{Mg.}$

\section{Experimental setup}

P. acei were provided from a local commercial aquarium (Afyonkarahisar, Turkey). Fish were then transferred to the aquaculture laboratory of Egirdir Fisheries Faculty, Suleyman Demirel University, Isparta, Turkey. A total of 75 broodstock (mean weight $6 \mathrm{~g}$ ) were randomly stocked $(4+: 1 \overbrace{}^{\Uparrow})$ in 15 aquariums $(70 \times 30 \times 40 \mathrm{~cm})$ for 90 days. Shelters were placed in the aquariums containing the fish, and the water was well aerated and filtered. The water temperature was maintained at a mean of $27^{\circ} \mathrm{C}$. The temperature of the aquariums was maintained at a constant by a thermostat heater. The dissolved oxygen rate ranged from 5 to $7 \mathrm{mg} \mathrm{L}^{-1}$ during the experiment. Experimental groups were fed by hand, ad libitum twice daily (8:30 and 20:30). The aquariums were cleaned daily by siphoning out from the waste feed and feces.

\section{Growth parameters}

The growth parameters were calculated according to the following formulas;

Specific Growth Rate $(\mathrm{SGR})\left(\%\right.$ day $\left.^{-1}\right)=((\ln \mathrm{FBW}-\ln \mathrm{IBW}) / \mathrm{T}) * 100$

Feed Conversion Ratio $(\mathrm{FCR})=$ Feed intake/weight gain,

Survival rate $(\%)=$ Final fish number/initial fish number $) * 100$

$\mathrm{T}$ time (days), FBW; Final body weight, IBW; Initial body weight

\section{Pigmentation Analysis}

Skin and tail color measurements were performed at the beginning and the end of the experiment with a colorimeter (Konica Minolta CR 300). Skin and tail color parameters of $\mathrm{L}^{*}, \mathrm{a}^{*}, \mathrm{~b}^{*}$ were measured from the regions close to the lateral line and dorsal section (CIE, 1986) after fish were put to sleep with an anesthetic (MS-222 $75 \mathrm{mg} / \mathrm{L})$. All of the fish were used color measuring. Chroma $(\mathrm{Ch})$ and hue angle $\left(\mathrm{H}^{\circ}\right)$ was calculated with the aid of $\mathrm{a}^{*}$ and $\mathrm{b}^{*}$ values. $\mathrm{L}^{*}:(+)$ brightness, $(-)$ darkness, $\mathrm{a}^{*}:(+)$ redness, $(-)$ greenness, $\mathrm{b}^{*}:(+)$ yellowness, $(-)$ blueness (Nickell and Bromage, 1998). In this system, $\mathrm{L} *$ value is the brightness or luminance variable and the values a* and $\mathrm{b} *$ are the chromaticity coordinates $(\mathrm{a} *<0$ green color, $\mathrm{a} *>0$ red color, $\mathrm{b} *<0$ blue color, $\mathrm{b} *>0$ yellow color) that were determined (Yesilayer et al., 2020). Chroma (Ch) indicates color intensity and brightness and was calculated with the equation of $\mathrm{Ch}=\left(\mathrm{a}^{*} 2+\mathrm{b} * 2\right) 1 / 2$. The hue angle is calculated with is calculated with following formulas; if $\left(+a^{*},+b^{*}\right), \operatorname{Hab}^{\circ}=\operatorname{ArcTan}\left(b^{*} / a^{*}\right)$; if $\left(-a^{*},+b^{*}\right)$ and $(-$ $\left.a^{*},-b^{*}\right), \mathrm{H}^{\circ} \mathrm{ab}=180+\operatorname{ArcTan}\left(\mathrm{b}^{*} / \mathrm{a}^{*}\right)$; if $\left(+\mathrm{a}^{*},-\mathrm{b}^{*}\right), \mathrm{Hab}^{\circ}=360+\operatorname{ArcTan}\left(\mathrm{b}^{*} / \mathrm{a}^{*}\right)($ McLellan et al. 1995). For hue $\left(\mathrm{H}^{\circ} \mathrm{ab}\right), 0^{\circ}$ indicates a tone of red, $90^{\circ}$ a tone of yellow, $180^{\circ}$ a tone of green and $270^{\circ}$ a tone of blue (Hunt, 1977; Yeşilayer and Erdem, 2011). 


\section{Ethics statement}

Suleyman Demirel University Animal Experiments Local Ethics Committee, Meeting date: 06.07.2017, Meeting number: 04, Decisions number: 02.

\section{Statistical Analysis}

The significance of differences between experimental groups was analyzed by one-way analysis of variance (ANOVA). All data were calculated by using the SPSS computer program (SPSS 20.00). The Duncan test was used to determine the differences among treatment means $(\mathrm{P}<0.05)$.

\section{RESULTS}

\section{Growth performance and survival rate of $P$. acei (Regan 1922)}

The results on the growth performance and survival rate of $P$. acei were given in Table 2 . There were no significant differences between final weight, weight gain SGR (Specific growth rate), FCR (Feed Conversion Ratio), and survival rate of $P$. acei fed with experimental diets ( $\mathrm{P}>0.05)$.

Table 2. Growth performance and survival rate of P. acei (Regan 1922)

\begin{tabular}{|c|c|c|c|c|c|c|c|c|}
\hline Growth Performance & $\mathbf{C}$ & $\mathbf{T 1}$ & T3 & T5 & T7 & df & $\mathbf{F}$ & $\mathbf{P}$ \\
\hline Initial mean weight $(\mathrm{g})$ & $6.27 \pm 0.43$ & $6.30 \pm 0.36$ & $6.13 \pm 0.34$ & $6.39 \pm 0.36$ & $6.39 \pm 0.22$ & 4 & 0.07 & 0.99 \\
\hline Initial mean length $(\mathrm{cm})$ & $7.75 \pm 0.16$ & $7.65 \pm 0.20$ & $7.84 \pm 0.15$ & $7.83 \pm 0.13$ & $7.70 \pm 0.11$ & 4 & 0.26 & 0.90 \\
\hline Final mean weight $(\mathrm{g})$ & $8.65 \pm 0.55$ & $7.61 \pm 0.59$ & $8.08 \pm 0.43$ & $7.55 \pm 0.45$ & $7.52 \pm 0.80$ & 4 & 0.79 & 0.54 \\
\hline Final mean length $(\mathrm{cm})$ & $8.60 \pm 0.22$ & $8.52 \pm 0.21$ & $8.55 \pm 0.21$ & $8.60 \pm 0.19$ & $8.52 \pm 0.29$ & 4 & 0.03 & 0.99 \\
\hline $\begin{array}{l}\text { Feed Conversion Ratio } \\
\text { (FCR) }\end{array}$ & $3.10 \pm 0.30$ & $4.37 \pm 0.27$ & $4.41 \pm 0.63$ & $4.57 \pm 0.41$ & $3.55 \pm 0.42$ & 4 & 2.27 & 0.13 \\
\hline $\begin{array}{l}\text { Specific growth rate } \\
\left(\mathrm{SGR} ; \% \mathrm{day}^{-1}\right)\end{array}$ & $0.36 \pm 0.04$ & $0.28 \pm 0.04$ & $0.31 \pm 0.03$ & $0.18 \pm 0.09$ & $0.17 \pm 0.01$ & 4 & 2.49 & 0.13 \\
\hline Weight gain (g) & $2.23 \pm 0.23$ & $0.97 \pm 0.27$ & $1.67 \pm 0.37$ & $1.25 \pm 0.36$ & $0.92 \pm 0.19$ & 4 & 3.47 & 0.05 \\
\hline Survival rate $(\%)$ & $92.13 \pm 3.10$ & $91.44 \pm 4.00$ & $95.09 \pm 2.78$ & $91.91 \pm 3.66$ & $90.08 \pm 3.46$ & 4 & 0.26 & 0.90 \\
\hline
\end{tabular}

\section{Pigmentation body and tail of $P$. acei (Regan 1922)}

The results on the pigmentation body and tail of $P$. acei were presented in Tables 3 and 4 .

The blue indicator $-\mathrm{b}$ value in the body color of the female increased with the addition of turmeric, the highest $-b$ values were found in T3 and T7 groups. At the same time, the L values increased with the addition of turmeric, namely the color opened. $\mathrm{H}_{\mathrm{ab}}$ values were determined in the blue area and decreased with the addition of turmeric, It approached $270^{\circ}$ (blue). The highest $\mathrm{H}_{\mathrm{ab}}$ value was determined in the control group $\left(325^{\circ}\right)(\mathbf{P}<\mathbf{0 . 0 5})$. Ch brightness value increased with the addition of turmeric. The highest $\mathrm{Ch}$ values were determined in the T3 and T5 groups $(\mathrm{P}<0.05)$.

The blue indicator $-\mathrm{b}$ values in male body color were high in all turmeric supplemented groups compared to the control group $(\mathrm{P}<0.05) . \mathrm{H}_{\mathrm{ab}}$ values were determined in the blue area and increased with the addition of turmeric and it moved away from $270^{\circ}$. The highest $\mathrm{H}_{\mathrm{ab}}$ values were found in $\mathrm{T} 1$ $\left(290^{\circ}\right)$ and T5 $\left(291^{\circ}\right)$ groups.

The yellow color indicator $+b$ value in the color of the female tail increased with the addition of turmeric. The highest $+\mathrm{b}$ value was determined in the $\mathrm{T} 7$ group $(\mathrm{P}<0.05)$. $\mathrm{L}$ values increased with the addition of turmeric, namely the color opened. The highest $\mathrm{L}$ value was found in the T1 group. Especially in the $\mathrm{T} 7$ group, the chroma brightness value was found to be higher than the control $(\mathrm{P}<0.05)$.

The yellow color indicator $+\mathrm{b}$ value in the male tail color increased with the addition of turmeric. The highest $+b$ value was found in $\mathrm{T} 3$ group $(\mathrm{P}<0.05)$. $\mathrm{H}_{\mathrm{ab}}$ values were determined in the yellow area and increased with the addition of turmeric and it moved away from $90^{\circ}$. The highest $\mathrm{H}_{\mathrm{ab}}$ value was determined in the T3 group (97.51) group $(\mathrm{P}<0.05)$. Ch brightness value increased with the addition of turmeric. The highest was detected in the $\mathrm{T} 3$ group $(\mathrm{P}<0.05)$. 
Table 3. Tail and body $\mathrm{L}^{*} \mathrm{a} * \mathrm{~b} *$ pigmentation of $P$. acei (Regan 1922) (Mean \pm SE)

\begin{tabular}{|c|c|c|c|c|c|c|c|c|c|}
\hline \multicolumn{10}{|c|}{ Body } \\
\hline \multirow{7}{*}{ Female } & & $\mathbf{C}$ & T1 & T3 & T5 & T7 & df & $\mathbf{F}$ & $\mathbf{P}$ \\
\hline & L*initial & $40.92 \pm 5.31$ & $40.92 \pm 5.31$ & $40.92 \pm 5.31$ & $40.92 \pm 5.31$ & $40.92 \pm 5.31$ & - & - & - \\
\hline & L*90th day & $34.86 \pm 1.11^{\mathrm{a}}$ & $39.78 \pm 1.13^{\mathrm{b}}$ & $39.34 \pm 1.08^{\mathrm{ab}}$ & $37.03 \pm 0.70^{\mathrm{ab}}$ & $40.54 \pm 1.68^{b}$ & 4 & 4.38 & 0.00 \\
\hline & $\mathrm{a}^{*}$ initial & $2.15 \pm 0.57$ & $2.15 \pm 0.57$ & $2.15 \pm 0.57$ & $2.15 \pm 0.57$ & $2.15 \pm 0.57$ & - & - & - \\
\hline & $\mathrm{a}^{*}$ 90th day & $2.08 \pm 0.10$ & $2.31 \pm 0.14$ & $2.40 \pm 0.14$ & $2.46 \pm 0.13$ & $2.16 \pm 0.19$ & 4 & 1.49 & 0.21 \\
\hline & b*initial & $-2.10 \pm 0.80$ & $-2.10 \pm 0.80$ & $-2.10 \pm 0.80$ & $-2.10 \pm 0.80$ & $-2.10 \pm 0.80$ & - & - & - \\
\hline & b*90th day & $-1.49 \pm 0.17^{\mathrm{a}}$ & $-2.20 \pm 0.22^{\mathrm{ab}}$ & $-2.61 \pm 0.25^{b}$ & $-2.35 \pm 0.25^{\mathrm{ab}}$ & $-2.61 \pm 0.27^{b}$ & 4 & 4.56 & 0.00 \\
\hline \multirow{6}{*}{ Male } & L*initial & $32.30 \pm 2.96$ & $32.30 \pm 2.96$ & $32.30 \pm 2.96$ & $32.30 \pm 2.96$ & $32.30 \pm 2.96$ & - & - & - \\
\hline & L*90th day & $30.04 \pm 3.39$ & $33.06 \pm 3.04$ & $39.14 \pm 1.87$ & $30.96 \pm 1.15$ & $34.93 \pm 3.37$ & 4 & 1.77 & 0.17 \\
\hline & $\mathrm{a}^{*}$ initial & $0.70 \pm 0.37$ & $0.70 \pm 0.37$ & $0.70 \pm 0.37$ & $0.70 \pm 0.37$ & $0.70 \pm 0.37$ & & & \\
\hline & a*90th day & $0.43 \pm 0.18^{b}$ & $2.30 \pm 0.54^{\mathrm{a}}$ & $1.23 \pm 0.24^{\mathrm{ab}}$ & $1.86 \pm 0.16^{\mathrm{ab}}$ & $1.63 \pm 0.62^{\mathrm{ab}}$ & 4 & 3.63 & 0.03 \\
\hline & b*initial & $-3.74 \pm 0.89$ & $-3.74 \pm 0.89$ & $-3.74 \pm 0.89$ & $-3.74 \pm 0.89$ & $-3.74 \pm 0.89$ & & & \\
\hline & $\mathrm{b}^{* 90 \text { th day }}$ & $-3.16 \pm 0.81^{\mathrm{a}}$ & $-5.72 \pm 0.42^{b}$ & $-5.25 \pm 0.34^{b}$ & $-5.06 \pm 1.01^{b}$ & $-5.74 \pm 0.50^{b}$ & 4 & 3.12 & 0.04 \\
\hline \multicolumn{10}{|c|}{ Tail } \\
\hline \multirow{7}{*}{ Female } & & $\mathbf{C}$ & T1 & T3 & T5 & T7 & df & $\mathbf{F}$ & $\mathbf{P}$ \\
\hline & L*initial & $52.04 \pm 4.66$ & $52.04 \pm 4.66$ & $52.04 \pm 4.66$ & $52.04 \pm 4.66$ & $52.04 \pm 4.66$ & - & - & - \\
\hline & L*90th day & $54.47 \pm 2.11^{\mathrm{c}}$ & $68.05 \pm 0.74^{\mathrm{a}}$ & $60.84 \pm 1.82^{\mathrm{cb}}$ & $62.24 \pm 1.47^{\mathrm{ab}}$ & $62.04 \pm 1.61^{\mathrm{ab}}$ & 4 & 9.20 & 0.00 \\
\hline & $\mathrm{a}^{*}$ initial & $-1.38 \pm 1.29$ & $-1.38 \pm 1.29$ & $-1.38 \pm 1.29$ & $-1.38 \pm 1.29$ & $-1.38 \pm 1.29$ & - & - & - \\
\hline & a*90th day & $-1.46 \pm 0.38^{\mathrm{ab}}$ & $-2.27 \pm 0.24^{b}$ & $-0.17 \pm 0.80^{\mathrm{a}}$ & $-2.55 \pm 0.33^{b}$ & $-2.54 \pm 0.31^{b}$ & 4 & 4.53 & 0.00 \\
\hline & $\mathrm{b}^{* \text { initial }}$ & $24.44 \pm 3.32$ & $24.44 \pm 3.32$ & $24.44 \pm 3.32$ & $24.44 \pm 3.32$ & $24.44 \pm 3.32$ & - & - & - \\
\hline & b*90th day & $18.08 \pm 1.64^{\mathrm{c}}$ & $23.59 \pm 1.08^{\mathrm{ab}}$ & $23.08 \pm 1.55^{\mathrm{cb}}$ & $24.28 \pm 1.11^{\mathrm{ab}}$ & $28.92 \pm 0.76^{\mathrm{a}}$ & 4 & 7.99 & 0.00 \\
\hline \multirow{6}{*}{ Male } & L*initial & $52.83 \pm 4.15$ & $52.83 \pm 4.15$ & $52.83 \pm 4.15$ & $52.83 \pm 4.15$ & $52.83 \pm 4.15$ & - & - & - \\
\hline & L*90th day & $49,57 \pm 3.11^{\mathrm{ab}}$ & $69.04 \pm 1.01^{\mathrm{c}}$ & $66.31 \pm 1.65^{\mathrm{c}}$ & $61.49 \pm 2.98^{\mathrm{cb}}$ & $46.58 \pm 9.40^{\mathrm{a}}$ & 4 & 9.20 & 0.00 \\
\hline & $\mathrm{a}^{*}$ initial & $-1.77 \pm 2.09$ & $-1.77 \pm 2.09$ & $-1.77 \pm 2.09$ & $-1.77 \pm 2.09$ & $-1.77 \pm 2.09$ & - & - & - \\
\hline & a*90th day & $-0.75 \pm 0.19^{c}$ & $-1.89 \pm 0.50^{\mathrm{cb}}$ & $-3.64 \pm 0.28^{\mathrm{a}}$ & $-2.43 \pm 0.22^{\mathrm{ba}}$ & $-2.09 \pm 0.26^{\mathrm{cb}}$ & 4 & 11.65 & 0.00 \\
\hline & b*initial & $21.09 \pm 3.28$ & $21.09 \pm 3.28$ & $21.09 \pm 3.28$ & $21.09 \pm 3.28$ & $21.09 \pm 3.28$ & - & - & - \\
\hline & b*90th day & $15.41 \pm 1.82^{\mathrm{c}}$ & $22.34 \pm 0.88^{b}$ & $27.62 \pm 0.43^{\mathrm{a}}$ & $20.85 \pm 0.25^{\mathrm{b}}$ & $18.87 \pm 0.99^{\mathrm{ab}}$ & 4 & 17.67 & 0.00 \\
\hline
\end{tabular}

In the same line, values with different superscript letters are significantly different $(\mathrm{P}<0.05)$

$\mathrm{L}^{*}:(+)$ brightness, $(-)$ darkness, $\mathrm{a}^{*}:(+)$ redness, $(-)$ greenness, $\mathrm{b}^{*}:(+)$ yellowness, $(-)$ blueness (Nickell and Bromage, 1998). 
Table 4. Tail and body $\mathrm{H}^{\circ} \mathrm{ab}$ and Chroma (Ch) values of $P$. acei (Regan 1922) (Mean $\left.\pm \mathrm{SE}\right)$

\begin{tabular}{|c|c|c|c|c|c|c|c|c|c|}
\hline \multicolumn{10}{|c|}{ Body } \\
\hline \multirow{5}{*}{ Female } & & $\mathrm{C}$ & T1 & T3 & T5 & T7 & df & $\mathbf{F}$ & $\overline{\mathbf{P}}$ \\
\hline & $\mathrm{H}^{\mathrm{o}} \mathrm{ab}$ initial & $315.02 \pm 3.58$ & $315.02 \pm 3.58$ & $315.02 \pm 3.58$ & $315.02 \pm 3.58$ & $315.02 \pm 3.58$ & & & \\
\hline & $\mathrm{H}^{\mathrm{O}} \mathrm{ab}$ 90th day & $325.19 \pm 3.65^{b}$ & $317.95 \pm 3.32^{\mathrm{ab}}$ & $315.49 \pm 3.58^{\mathrm{ab}}$ & $316.74 \pm 3.20^{\mathrm{ab}}$ & $310.71 \pm 3.33^{\mathrm{a}}$ & 4 & 2.33 & 0.06 \\
\hline & Ch initial & $2.67 \pm 0.14$ & $2.67 \pm 0.14$ & $2.67 \pm 0.14$ & $2.67 \pm 0.14$ & $2.67 \pm 0.14$ & & & \\
\hline & Ch 90th day & $2.67 \pm 0.10^{\mathrm{a}}$ & $3.17 \pm 0.16^{\mathrm{ab}}$ & $3.68 \pm 0.21^{\mathrm{b}}$ & $3.45 \pm 0.20^{\mathrm{b}}$ & $3.31 \pm 0.26^{\mathrm{ab}}$ & 4 & 5.21 & 0.00 \\
\hline \multirow{4}{*}{ Male } & $\mathrm{H}^{\mathrm{o}} \mathrm{ab}$ initial & $279.15 \pm 1.71$ & $279.15 \pm 1.71$ & $279.15 \pm 1.71$ & $279.15 \pm 1.71$ & $279.15 \pm 1.71$ & & & \\
\hline & $\mathrm{H}^{\circ} \mathrm{ab}$ 90th day & $275.23 \pm 2.24^{\mathrm{a}}$ & $290.79 \pm 3.70^{b}$ & $283.83 \pm 3.11^{\mathrm{ab}}$ & $291.77 \pm 3.52^{b}$ & $285.07 \pm 5.42^{\mathrm{ab}}$ & 4 & 3.33 & 0.03 \\
\hline & Ch initial & $4.10 \pm 0.26$ & $4.10 \pm 0.26$ & $4.10 \pm 0.26$ & $4.10 \pm 0.26$ & $4.10 \pm 0.26$ & & & \\
\hline & Ch 90th day & $4.33 \pm 0.21$ & $5.46 \pm 0.81$ & $5.43 \pm 0.72$ & $4.82 \pm 1.89$ & $5.46 \pm 0.12$ & 4 & 1.28 & 0.32 \\
\hline \multicolumn{10}{|c|}{ Tail } \\
\hline \multirow{5}{*}{ Female } & & $\mathbf{C}$ & T1 & T3 & T5 & T7 & df & $\mathbf{F}$ & $\mathbf{P}$ \\
\hline & $\mathrm{H}^{\mathrm{o}} \mathrm{ab}$ initial & $93.80 \pm 0.63$ & $93.80 \pm 0.63$ & $93.80 \pm 0.63$ & $93.80 \pm 0.63$ & $93.80 \pm 0.63$ & & & \\
\hline & $\mathrm{H}^{\mathrm{o}} \mathrm{ab}$ 90th day & $95.37 \pm 0.66$ & $95.35 \pm 0.48$ & $95.51 \pm 0.58$ & $96.11 \pm 0.52$ & $94.91 \pm 0.54$ & 4 & 0.56 & 0.68 \\
\hline & Ch initial & $23.83 \pm 0.59$ & $23.83 \pm 0.59$ & $23.83 \pm 0.59$ & $23.83 \pm 0.59$ & $23.83 \pm 0.59$ & & & \\
\hline & Ch 90th day & $24.24 \pm 1.40^{\mathrm{a}}$ & $24.25 \pm 1.00^{\mathrm{a}}$ & $24.88 \pm 1.28^{\mathrm{ab}}$ & $25.66 \pm 0.86^{\mathrm{ab}}$ & $29.05 \pm 0.77^{\mathrm{c}}$ & 4 & 3.35 & 0.02 \\
\hline \multirow{4}{*}{ Male } & $\mathrm{H}^{\mathrm{o}} \mathrm{ab}$ initial & $96.36 \pm 1.38$ & $96.36 \pm 1.38$ & $96.36 \pm 1.38$ & $96.36 \pm 1.38$ & $96.36 \pm 1.38$ & & & \\
\hline & $\mathrm{H}^{\circ} \mathrm{ab}$ 90th day & $92.91 \pm 0.83^{\mathrm{a}}$ & $94.71 \pm 1.05^{\mathrm{ab}}$ & $97.51 \pm 0.56^{b}$ & $96.65 \pm 0.61^{\mathrm{ab}}$ & $94.53 \pm 1.49^{\mathrm{ab}}$ & 4 & 5.02 & 0.01 \\
\hline & Ch initial & $23.71 \pm 0.79$ & $23.71 \pm 0.79$ & $23.71 \pm 0.79$ & $23.71 \pm 0.79$ & $23.71 \pm 0.79$ & & & \\
\hline & Ch 90th day & $17.42 \pm 2.05^{\mathrm{a}}$ & $22.44 \pm 0.92^{b}$ & $27.86 \pm 0.43^{\mathrm{c}}$ & $20.99 \pm 0.25^{\mathrm{ab}}$ & $18.95 \pm 1.03^{\mathrm{ab}}$ & 4 & 17.03 & 0.00 \\
\hline
\end{tabular}

In the same line, values with different superscript letters are significantly different $(\mathrm{P}<0.05)$ 


\section{DISCUSSION}

In the present study, there were no differences in growth performance, FCR, and survival rate of $P$. acei fed with diets with addition turmeric different ratios $(0,1,3,5$, and $7 \%)$ compare to the control group. Similarly, Mahmoud et al., (2014) reported that Oreochromis niloticus fed diets added 0, 0.25, and $0.50 \%$ turmeric powder had not different final weights. Ferreira et al., (2017) indicated that turmeric powder supplementation $(2,4,6,8$, and $10 \%)$ had not an effect on the growth of juvenile Astyanax aff. bimaculatus. Sahu et al., (2008) determined that growth performance was no affected in Labeo rohita fed the basal diet with addition turmeric powder different ratio $(0.01,0.05,0.1$, and 0.5 $\%$ ), but the highest survival ratio was found in group addition turmeric $0.5 \%$. Hassan, (2016) pointed that there were no significant differences in body weight gain of hens fed dietary added turmeric powder $(0,2$, and $4 \%)$. Alagawany et al., (2016) reported that growth performance was no affected in rabbits fed the basal diet with addition turmeric different ratios $(0.2,0.4$, and $0.6 \%)$.

However, Rebecca and Bhavan, (2014) obtained the better weight gain and survival rate in all groups compared to the control in $M$. rosenbergii fed with diets containing A. sativum, Z. officinale, and $C$. longa in three different ratios $(1 \%, 3 \%$, and 5\%). Abdelwahab and El-Bahr, (2012) indicated the higher growth levels according to the control were obtained in Sea Bass fed diets supplemented with different ratios $(0.5,1.0 \%)$ with a mix of turmeric powder and black cumin seeds (Nigella sativa) (1:1 ratio). Akdemir et al., (2017) observed to increase in body weight, feed intake, and weight gain fed with curcumin-supplemented diet at $0.02 \%$ of diet levels of high stocking density conditions in trout. Mukherjee et al., (2009) observed SGR in Poecilia reticulata fed supplemented diet with turmeric powder $(0.09 \%)$. Arunkumar et al., (2016) indicated that the best of FCR and weight gain were obtained in carp fed with copepod enriched with turmeric powder $(0.9 \mathrm{~g} / \mathrm{l})$. Poongodi et al., (2012) found the better growth performance, SGR, feed conversion efficiency, and survival rate in all groups compared to the control in Macrobrachium rosenbergii postlarvae fed with diets containing (1 $\%)$ Allium sativum, Zingiber officinale, Curcuma longa and Trigonella foenum-graecum powder. Yusuf et al., (2017) determined in the $0.4 \%$ group the highest growth in $O$. niloticus fed with a diet supplemented with different ratio turmeric powder. The reasons for the differences between the studies with the current study may be the following reasons; in the present study, the numbers of females were higher than males because the males are a fighter. $P$. acei species gives offspring every two months. Therefore, the females maybe have used for gonad development most of the nutrients obtained from feed. As results of this, the growth may be negatively affected by gonadal development. In addition, unlike most other studies, higher rates of tumeric powder were used in this study.

There were a few studies on the effects of turmeric in fish pigmentation. Mukherjee et al., (2009) reported that high pigmentation was observed in the caudal fin and muscle of fish ( $P$. reticulata) fed with diets added turmeric powder $(0.09 \%)$. However, Nascimento et al., (2019) indicated that supplementing to diets of turmeric powder $(0-2.5 \%)$ no improved the orange pattern of skin pigmentation of Trichogaster labiosa orange thick-lipped gourami. Similarly, in the present study, the pigmentation increased statistically by increasing of turmeric powder ratio in diets. However, the pigmentation of groups supplemented turmeric powder was visually not different from the color of the control group. As a result of the study, skin and tail pigmentation and growth performance of $P$. acei were not improved by supplementing with turmeric powder to diets.

\section{ACKNOWLEDGEMENT}

This study was supported by Süleyman Demirel University, Scientific Research Project Grant (SDUBAP- 5009-YL1-17)

\section{REFERENCES}

Abdelwahab, A. M. \& S.M. El-Bahr. (2012). Influence of black cumin seeds (Nigella sativa) and turmeric (Curcuma longa Linn.) mixture on performance and serum biochemistry of Asian Sea Bass, Lates calcarifer. World Journal of Fish and Marine Sciences 4(5), 496-503.

Akdemir, F., Orhan, C. Tuzcu, M. Sahin, N. Juturu, V. \& Sahin K. (2017). The efficacy of dietary curcumin on growth performance, lipid peroxidation and hepatic transcription factors in rainbow trout Oncorhynchus mykiss (Walbaum) reared under different stocking densities. Aquaculture Research 48(8): 4012-4021.

Alpbaz, A., \& Hoşsucu, H. (1996). Culture of freshwater fishes. Ege University, Faculty of Fisheries. Izmir, Turkey. pp 24. 
Alagawany, M., Ashour, E.A.\& Reda, F.M. (2016). Effect of dietary supplementation of garlic (Allium sativum) and turmeric (Curcuma longa) on growth performance, carcass traits, blood profile and oxidative status in growing rabbits. Annals of Animal Science, 16(2), 489-505.

Ambati, R.R., Gogisetty, D. Aswathanarayana, R.G. Ravi, S. Bikkina, P.N. Bo L. \& Yuepeng, S. (2019). Industrial potential of carotenoid pigments from microalgae: Current trends and future prospects. Critical Reviews in Food Science and Nutrition, 59 (12), 1880-1902.

Arunkumar, P., Ramasubramanian, V. \& Munirasu, S. (2016). Effect of Curcuma longa enriched Mesocylops thermocyclopoides on fresh water fish, Cyprinus carpio International Journal of Research and Development in Pharmacy and Life Sciences, 6 (1), 2484-2492.

Brine Shrimp Direct, (2005). NatuRose: Natural Astaxanthin as a pigment source for ornamental fish and animals. https://www.brineshrimpdirect.com/about-us/articles/natural-astaxanthin/. Accessed 12 February 2019.

Chainani-Wu, N. (2003). Safety and anti-inflammatory activity of curcumin: a component of tumeric (Curcuma longa). The Journal of Alternative and Complementary Medicine, 9 (1), 161-168.

Carbonell-Capella, J.M., Buniowska, M. Barba, F.J. Esteve, M.J. \& Frígola, A. (2014). Analytical methods for determining bioavailability and bioaccessibility of bioactive compounds from fruits and vegetables: A review. Comprehensive Reviews in Food Science and Food Safety, 13 (2), 155-171.

Ferreira, P.D.M.F., Martins, M.T.S., Caldas, D.W. Romes, G J., de Oliveira, J.M. Salaro A.L. \& Zuanon, J.A.S. (2017). Curcuma longa as additive in the diet for Astyanax aff. bimaculatus. Fish Physiology and Biochemistry, 43 (3), 691-702.

Hassan, S. M. (2016). Effects of adding different dietary levels of Turmeric (Curcuma longa Linn) powder on productive performance and egg quality of laying hens. International Journal of Poultry Science 15(4), 156-160.

Hatlen, B., Arnmesan, A., Jobling, M. \& Bjerkeng, B. (1997). Carotenoid pigmentation in relation to feed intake, growth and social integration in Arctic char, Salvelinus alpinus (L.), from two anadromous strains. Aquaculture Nutrition, 3 (3), 189-199.

Hekimoglu, M.A. (2005). A study on growing and coloring of gold fish in colored tanks (Cyprinus auratus, 1778). Journal of Fisheries and Aquatic Sciences, 22 (1), 137-141.

Hunt, R.W.G., 1977. The specification of colour appearance. 1. Concepts and terms. Colour Res. Appl. 2, 55-68.

Kop, A., \& Durmaz, Y. (2008). The effect of synthetic and natural pigments on the colour of the cichlids (Cichlasoma severum sp., Heckel 1840). Aquaculture International, 16 (2), 117-122.

Mahmoud, M.M.A., El-Lamie, M.M.M., Dessouki, A.A. \& Yusuf, M.S. (2014). Effect of turmeric (Curcuma longa) supplementation on growth performance, feed utilization, and resistance of nile tilapia (Oreochromis niloticus) to Pseudomonas fluorescens Challenge. Global Research Journal of Fishery Science and Aquaculture, 1 (12), 026-033.

McLellan, M. R., Lind, L. R., \& Kime, R. W. (1995). Hue angle determinations and statistical analysis for multiquadrant Hunter L, a, b data. Journal of food quality, 18(3), 235-240.

Mohammed, M.K., \& Mohd, M.K. (2011). Production of carotenoids (antioxidants/colourant) in Spirulina platensis in response to indole acetic acid (IAA).

Mukherjee, A., Mandal, B. \& Banerjee, S. (2009). Turmeric as a carotenoid source on pigmentation and growth of fantail guppy, Poecilia reticulata. Proceedings of the Zoological Society, 62 (2), 119-123.

Murthy, K.C., Vanitha, A., Rajesha, J., Swamy, M.M., Sowmya P.R \& Ravishankar, G.A. (2005). In vivo antioxidant activity of carotenoids from Dunaliella salina a green microalga. Life Sciences, 76 (12), 1381-1390.

Nascimento, L.D.S., Reis, S.M., Ferreira, P.D.M.F., Kanashiro, M.Y., Salaro, A.L., \& Zuanon, J.A.S. (2019). Effects of Curcuma longa rhizome on growth, skin pigmentation, and stress tolerance after transport of Trichogaster labiosa. Revista Brasileira de Zootecnia, 48.

Nickell, D. C., \& Bromage, N. R. (1998). The effect of dietary lipid level on variation of flesh pigmentation in rainbow trout (Oncorhynchus mykiss). Aquaculture, 161(1-4), 237-251.

Poongodi, R., Bhavan, P.S. Muralisankar, T. \& Radhakrishnan, S. (2012). Growth promoting potential of garlic, ginger, turmeric and fenugreek on the freshwater prawn Macrobrachium rosenbergii. International Journal of Pharma and Bio Sciences, 3(4), 914-926.

Parry, J.W.L, Carleton, K.L., Spady, T., Carboo, A., Hunt, D.M. \& Bowmaker, J.K. (2005). Mix and match color vision: tuning spectral sensitivity by differential opsin gene expression in Lake Malawi cichlids. Current Biology, 15, 1734-1739.

Rebecca, A.A. \& Bhavan, P.S. (2014). Growth promotion and survival enhancement of the freshwater prawn Macrobrachium rosenbergii post larvae fed with Allium sativum, Zingiber officinale and Curcuma longa. International Journal of Pure and Applied Zoology, 2 (2), 138-149. 
Sahu, S., Das, B.K. Mishra, B.K., Pradhan, J., Samal, S.K. \& Sarangi, N. (2008). Effect of dietary Curcuma longa on enzymatic and immunological profiles of Rohu, Labeo rohita (ham.), infected with Aeromonas hydrophila. Aquaculture Research, 39 (16), 1720-1730.

Srikrishnan, R., Hirimuthugoda, N. \& Rajapakshe, W. (2017). Evaluation of growth performance and breeding habits of fighting fish (Betta splendens) under 3 diets and shelters. Journal of Survey in Fisheries Sciences, 3 (2), 50-65.

Sommer, T.R., Potts, W.T. \& Morrissy, N.M. (1991). Utilization of microalgal astaxanthin by rainbow trout (Oncorhynchus mykiss). Aquaculture, 94 (1),79-88.

Tayyem, R.F., Heath, D.D., Al-Delaimy, W.K. \& Rock, C.L. (2006). Curcumin content of turmeric and curry powders. Nutrition and Cancer, 55 (2), 126-131.

Yesilayer, N., Dogan, G. \& Erdem, M.. (2008). The use of natural carotenoid sources in fish feed. Journal of FisheriesSciences. Com, 2 (3), 241-251.

Yeşilayer, N. \& Erdem, M. (2011). Effects of oleoresin paprika (Capsicum annum) and synthetic carotenoids (Canthaxantin and Astaxanthin) on pigmentation levels and growth in rainbow trout Oncorhynchus mykiss W. Journal of Animal and Veterinary Advances, 10 (14), 1875-1882

Yeşilayer, N., Mutlu, G., \& Yıldırım, A. (2020). Effect of nettle (Urtica spp.), marigold (Tagetes erecta), alfalfa (Medicago sativa) extracts and synthetic xanthophyll (zeaxanthin) carotenoid supplementations into diets on skin pigmentation and growth parameters of electric yellow cichlid (Labidochromis caeruleus). Aquaculture, 520, 734964.

Yusuf, M.S., Hassan, M.A., Tag, H.M., Sarivistava, K., Reddy, P.G. \& Hassan, A.M. (2017). Influence of turmeric (Curcuma longa) on performance, histomorphology and microbiota of intestine in juvenile tilapia (Oreochromis niloticus). International Journal of Agricultural Sciences and Veterinary Medicine, 5 (1), 7-16. 